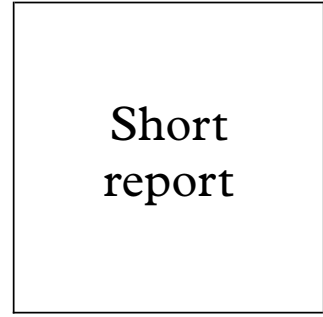

\section{Herpes simplex type 2 infection in a cohort aged 21 years}

\author{
J Eberhart-Phillips, N P Dickson, C Paul, J P Fawcett, D Holland, J Taylor, \\ A L Cunningham
}

Objectives: To measure the prevalence of HSV-2 antibodies in a birth cohort of 21 year old New Zealanders from whom detailed sexual histories had been obtained, and to assess the potential for HSV-2 serology in characterising a young adult population's risk for sexually transmitted diseases (STD).

Methods: Sera from 784 cohort members were tested using an indirect IgG enzyme linked immunoassay specific to the HSV-2 glycoprotein G. Positive results were confirmed by western blot.

Results: In all, 27 subjects were seropositive for HSV-2 (3.4\%), only seven of whom gave a history of genital herpes $(26 \%)$. Risk among females increased with lifetime number of partners, while risk for males increased with having a first partner who was aged 16 years or under.

Conclusions: The seroprevalence of HSV-2 infection in this cohort was low, but similar to that seen in several other populations in this age group. HSV-2 seropositivity did not appear to be a sensitive marker for high risk sexual activity in this young population. This may be because a critical mass of HSV-2 carriers has not accumulated among potential partners by age 21 years. (Sex Transm Inf 1998;74:216-218)

Keywords: HSV-2 genital infections, New Zealand

\section{Introduction}

Serological surveys of diverse populations have shown that infections with herpes simplex virus type 2 (HSV-2), the usual cause of genital herpes, are far more common than instances of manifest disease. ${ }^{1-7}$ Seropositivity of HSV-2 has been shown to be associated with number of sexual partners ${ }^{13^{5-7}}$ and past history of an STD. ${ }^{1378}$ For this reason seroprevalence rates among STD clinic attenders are not representative of the wider population. The observed link between sexual lifestyle and HSV-2 infection has led some investigators to suggest that HSV-2 antibodies may be used as a marker for high risk sexual behaviour between populations. $^{39}$

In this study we sought to measure the prevalence of HSV-2 antibodies in a large birth cohort of 21 year old New Zealanders from whom detailed information about sexual activity had been collected. We aimed to identify risk factors in this group for HSV-2 infection, and to assess the validity of using HSV-2 antibodies as a marker of high risk sexual activity in a population of young adults.

\section{Centre for Virus}

Research, Westmead

Research, University

of Sydney, Westmead, NSW, Australia

D Holland

J Taylor

A L Cunningham

Correspondence to: Department of Preventive and Social Medicine,

University of Otago Medical

School, PO Box 913,

Dunedin, New Zealand. years of age, they were invited to participate in a multidisciplinary assessment, which included questions about sexual activity presented by a computer. Details of the methods of collecting
Institutes of Health Dr Jason Eberhart-Phillips, the sexual history are described elsewhere. ${ }^{11}$

At the time of assessment all subjects were asked to provide a specimen of whole blood, from which serum was separated and stored at $-70^{\circ} \mathrm{C}$. Sera were then tested using an indirect cific to the HSV-2 glycoprotein G (gG-2). All sera positive by EIA for antibody to gG-2 were confirmed by western blot. This method has been validated elsewhere. ${ }^{12}$ Western blots were also performed on all sera from individuals who had reported a history of genital herpes.

Serological results were cross tabulated with social and demographic characteristics, and with variables related to sexual activity. For each variable prevalence ratios for HSV-2 seropositivity were calculated, together with $95 \%$ confidence intervals, using EPI-INFO version 6 statistical software.

\section{Results}

Of the 1037 members of the cohort formed at age 3, 1020 were believed to be alive at the time of the 21 year old assessment. Questions about sexual activity were answered by 935 cohort members $(91.7 \%)$. Serum was obtained for analysis from 784 subjects $(76.8 \%)$, including $775(82.9 \%)$ who had provided a sexual history. Demographic characteristics and reported sexual activity did not differ significantly between those who provided serum and those who declined.

Antibodies for HSV-2 were found in 27 specimens, yielding a seroprevalence of $3.4 \%$. There were 16 seropositive females $(4.3 \%)$ compared with 11 seropositive males $(2.7 \%$, $\mathrm{p}=0.22$ ). All reported previous sexual intercourse.

Of the 27 subjects with HSV-2 antibodies, IgG enzyme linked immunoassay (EIA) spe- 
Table 1 Association between prevalence of antibodies to herpes simplex type 2 and social and demographic characteristics in a cohort of 21 year olds

\begin{tabular}{|c|c|c|c|c|c|c|c|c|c|}
\hline \multirow[b]{2}{*}{ Characteristic } & \multicolumn{3}{|c|}{ Males $(n=410)$} & \multicolumn{3}{|c|}{ Females $(n=374)$} & \multicolumn{3}{|c|}{ Total $(n=784)$} \\
\hline & $\begin{array}{l}\text { No (\%) } \\
\text { positive }\end{array}$ & $\begin{array}{l}\text { Prevalence } \\
\text { ratio }\end{array}$ & $\begin{array}{l}95 \% \\
\text { Confidence } \\
\text { interval }\end{array}$ & $\begin{array}{l}\text { No (\%) } \\
\text { positive }\end{array}$ & $\begin{array}{l}\text { Prevalence } \\
\text { ratio }\end{array}$ & $\begin{array}{l}95 \% \\
\text { Confidence } \\
\text { interval }\end{array}$ & $\begin{array}{l}\text { No (\%) } \\
\text { positive }\end{array}$ & $\begin{array}{l}\text { Prevalence } \\
\text { ratio }\end{array}$ & $\begin{array}{l}95 \% \\
\text { Confidence } \\
\text { interval }\end{array}$ \\
\hline \multicolumn{10}{|l|}{ Socioeconomic status ${ }^{\star}$ : } \\
\hline Low $(n=608)$ & $10(3.1 \%)$ & 2.3 & $(0.3-17.4)$ & $13(4.7 \%)$ & 1.5 & $(0.4-5.0)$ & $23(3.8 \%)$ & 1.6 & $(0.6-4.5)$ \\
\hline High $(n=168)$ & $1(1.3 \%)$ & 1.0 & & $3(3.2 \%)$ & 1.0 & & $4(2.4 \%)$ & 1.0 & \\
\hline \multicolumn{10}{|l|}{ School qualification: } \\
\hline None $(n=92)$ & $5(8.3 \%)$ & 7.3 & $(1.4-36.4)$ & $1(3.1 \%)$ & 1.3 & $(0.2-11.5)$ & $6(6.5 \%)$ & 3.7 & $(1.2-11.3)$ \\
\hline 5 th/6th form cert $(n=333)$ & $4(2.4 \%)$ & 2.1 & $(0.4-11.3)$ & $11(6.5 \%)$ & 2.8 & $(0.9-8.6)$ & $15(4.7 \%)$ & 2.6 & $(1.0-6.6)$ \\
\hline High school cert or higher & & & & & & & & & \\
\hline$(\mathrm{n}=344)$ & $2(1.1 \%)$ & 1.0 & & $4(2.4 \%)$ & 1.0 & & $6(1.7 \%)$ & 1.0 & \\
\hline \multicolumn{10}{|l|}{ Place of residencet: } \\
\hline Outside Dunedin $(n=265)$ & $2(1.5 \%)$ & 0.5 & $(0.1-2.4)$ & $7(5.3 \%)$ & 1.4 & $(0.6-3.8)$ & $9(3.4 \%)$ & 1.0 & $(0.5-2.3)$ \\
\hline Dunedin $(n=515)$ & $8(2.9 \%)$ & 1.0 & & $9(3.7 \%)$ & 1.0 & & $17(3.3 \%)$ & 1.0 & \\
\hline
\end{tabular}

^Socioeconomic status derived at age 15 years from occupation of the subject's parents using the Elley Irving socioeconomic index for New Zealand occupations. Low SES corresponds to classes 4 to 6 on the Elley Irving scale. High SES corresponds to classes 1 to 3 .

†Normal place of residence at the time of the 21 year old assessment.

only seven $(26 \%)$ had reported a history of genital herpes. Five subjects had reported having other STDs, 13 had denied ever having an STD, and two did not answer the question about having had an STD.

A total of 17 subjects, 13 females and four males, had reported a history of genital herpes. Three did not provide serum for testing. Of the remaining 14 subjects, seven were seropositive for HSV-2. Six of the seven subjects who had reported a history of genital herpes but were seronegative for HSV-2 were found to have antibodies for HSV-1 by western blot. The other subject lacked antibodies for both HSV-1 and HSV-2.

Table 1 shows HSV-2 seroprevalence according to key social and demographic characteristics. Seropositivity was more likely among those with fewer school qualifications, especially among males.

In the analysis of seroprevalence according to reported sexual activity, 85 subjects who had reported no sexual experience by age 21 were excluded. Of the sexually experienced members of the cohort who gave serum for analysis, the median lifetime number of partners was six for males and four for females. The median number of partners in the past 3 years was four for males and two for females. The median age at first intercourse was 17 years for males compared with 16 years for females. The median age of the first partner was 17 years for males and 18 years for females.

Table 2 shows HSV-2 seroprevalence according to selected indicators of sexual activity. Lifetime number of partners was a strong predictor of HSV-2 seropositivity among females, especially females with 10 or more lifetime partners. None of the 66 females who reported having only one lifetime partner was seropositive for HSV-2.

Having a first partner who was age 16 years or under was associated with HSV-2 seropositivity for males, but not for females. None of the seropositive females reported having a first partner under age 16 years, or even under 18 years.

\section{Discussion}

The prevalence of HSV-2 antibodies found in this birth cohort was lower than that reported from STD clinics ${ }^{2-4} 7^{13}$ and from antenatal

Table 2 Association between prevalence of antibodies to herpes simplex type 2 and reported sexual activity in a cohort of 21 year olds *

\begin{tabular}{|c|c|c|c|c|c|c|c|c|c|}
\hline \multirow[b]{2}{*}{ Sexual activity } & \multicolumn{3}{|c|}{ Males $(n=342)$} & \multicolumn{3}{|c|}{ Females $(n=348)$} & \multicolumn{3}{|c|}{ Total $(n=690)$} \\
\hline & $\begin{array}{l}\text { No (\%) } \\
\text { positive }\end{array}$ & $\begin{array}{l}\text { Prevalence } \\
\text { ratio }\end{array}$ & $\begin{array}{l}95 \% \\
\text { Confidence } \\
\text { interval }\end{array}$ & $\begin{array}{l}\text { No (\%) } \\
\text { positive }\end{array}$ & $\begin{array}{l}\text { Prevalence } \\
\text { ratio }\end{array}$ & $\begin{array}{l}95 \% \\
\text { Confidence } \\
\text { interval }\end{array}$ & $\begin{array}{l}\text { No (\%) } \\
\text { positive }\end{array}$ & $\begin{array}{l}\text { Prevalence } \\
\text { ratio }\end{array}$ & $\begin{array}{l}95 \% \\
\text { Confidence } \\
\text { interval }\end{array}$ \\
\hline \multicolumn{10}{|l|}{ Lifetime number of partners: } \\
\hline 10 or more $(n=187)$ & $5(4.2 \%)$ & 1.3 & $(0.3-5.4)$ & $6(8.8 \%)$ & 9.2 & $(1.1-74.6)$ & $11(5.9 \%)$ & 2.9 & $(1.0-9.0)$ \\
\hline 3 to $9(n=297)$ & $3(2.2 \%)$ & 0.7 & $(0.1-3.3)$ & $7(4.4 \%)$ & 4.6 & $(0.6-36.7)$ & $10(3.5 \%)$ & 1.7 & $(0.5-5.3)$ \\
\hline 1 to $2(\mathrm{n}=199)$ & $3(3.2 \%)$ & 1.0 & & $1(1.0 \%)$ & 1.0 & & $4(2.0 \%)$ & 1.0 & \\
\hline \multicolumn{10}{|c|}{ Number of partners in past 3 years: } \\
\hline 10 or more $(n=99)$ & $4(6.2 \%)$ & 2.3 & $(0.4-12.4)$ & $3(8.8 \%)$ & 4.8 & $(0.8-27.6)$ & $7(7.0 \%)$ & 3.3 & $(1.0-10.9)$ \\
\hline 2 to $9(n=393)$ & $5(2.4 \%)$ & 0.9 & $(0.2-4.6)$ & $9(4.8 \%)$ & 2.6 & $(0.6-11.8)$ & $14(3.5 \%)$ & 1.6 & $(0.5-4.9)$ \\
\hline 0 to $1(n=185)$ & $2(2.6 \%)$ & 1.0 & & $2(1.8 \%)$ & 1.0 & & $4(2.2 \%)$ & 1.0 & \\
\hline \multicolumn{10}{|l|}{ Age at first sexual intercourse: } \\
\hline 16 years or less $(n=364)$ & $7(4.1 \%)$ & 1.8 & $(0.5-6.1)$ & $10(5.2 \%)$ & 1.8 & $(0.6-5.7)$ & $17(4.7 \%)$ & 1.9 & $(0.8-4.3)$ \\
\hline$>16$ years $(n=319)$ & $4(2.2 \%)$ & 1.0 & & $4(2.9 \%)$ & 1.0 & & $8(2.5 \%)$ & 1.0 & \\
\hline \multicolumn{10}{|l|}{ Age of first sexual partner: } \\
\hline 16 years or less $(n=247)$ & $9(5.3 \%)$ & 4.7 & $(1.1-21.3)$ & $0(0.0 \%)$ & 0.0 & $(0.0-1.80)$ & $9(3.6 \%)$ & 0.9 & $(0.4-2.1)$ \\
\hline$>16$ years $(n=434)$ & $2(1.1 \%)$ & 1.0 & & $15(5.8 \%)$ & 1.0 & & $17(3.9 \%)$ & 1.0 & \\
\hline \multicolumn{10}{|c|}{ Used condom during first sexual intercourse: } \\
\hline Yes $(n=361)$ & $4(2.4 \%)$ & 0.6 & $(0.2-2.1)$ & $6(3.1 \%)$ & 0.9 & $(0.3-3.1)$ & $10(2.8 \%)$ & 0.8 & $(0.3-1.7)$ \\
\hline No $(n=297)$ & $7(3.8 \%)$ & 1.0 & & $4(3.5 \%)$ & 1.0 & & $11(3.7 \%)$ & 1.0 & \\
\hline \multicolumn{10}{|c|}{ Used condom during last sexual intercourse: } \\
\hline Yes $(n=223)$ & $2(1.5 \%)$ & 0.4 & $(0.1-1.7)$ & $2(2.2 \%)$ & 0.4 & $(0.1-1.9)$ & $4(1.8 \%)$ & 0.4 & $(0.1-1.1)$ \\
\hline No $(n=461)$ & $9(4.1 \%)$ & 1.0 & & $12(5.0 \%)$ & 1.0 & & $21(4.6 \%)$ & 1.0 & \\
\hline \multicolumn{10}{|l|}{ Ever had an STD?: } \\
\hline Yes $(n=90)$ & $3(9.4 \%)$ & 3.8 & $(1.1-13.5)$ & $9(15.5 \%)$ & 8.4 & $(2.9-24.3)$ & $12(13.3 \%)$ & 6.1 & $(2.9-12.9)$ \\
\hline No $(n=593)$ & $8(2.5 \%)$ & 1.0 & & $5(1.8 \%)$ & 1.0 & & $13(2.2 \%)$ & 1.0 & \\
\hline
\end{tabular}

^Table excludes 85 subjects who reported no lifetime sexual experience. 
clinics, family planning clinics, and most general population surveys elsewhere. ${ }^{14-69}$ But the seroprevalence for this cohort was similar to that reported from studies of university students and blood donors belonging to this age group. $^{238}$ International experience suggests that HSV-2 seroprevalence in this cohort will climb considerably after the 21 year old assessment. ${ }^{14}$

The higher level of HSV-2 seroprevalence seen among females is typical of other general population surveys. ${ }^{356}$ This may occur because females tend to have older partners, who are more likely to be infected as a group, or there may be higher efficiency of genital HSV transmission from males to females than from females to males. ${ }^{15}$

As in other studies, most infections with HSV-2 in this cohort were inapparent. Clinical history of genital herpes alone appears to be too insensitive for measuring the true prevalence of HSV-2 infection in a population. In this cohort a history of genital herpes was also non-specific for HSV-2 infection. The proportion of genital herpes that was apparently due to HSV-1 was substantially higher than the $11 \%$ reported in a New Zealand survey of genital herpes isolates in $1983 .^{16}$

The lack of a clear association for males in this cohort between number of sexual partners and HSV-2 infection differs from most other surveys, and may simply be due to the small number of seropositive males. Surprisingly, two seropositive males had reported having only one partner each in their lifetimes. Perhaps the risk of HSV-2 infection is influenced by other factors such as the lifetime number and ages of partners of one's partner, and the duration of the partnership. A more expected pattern of HSV-2 infection was seen for females in this cohort when examining lifetime numbers of partners and partners in the past 3 years.

The finding that males in this cohort who had a younger first partner were at increased risk of HSV-2 infection appears not to have been investigated elsewhere. The reason for this finding is unclear, especially why it appears to increase HSV-2 risk only among males. This may be a chance finding, but it is possible that males who have younger first partners are at higher risk of HSV-2 for other reasons, or that younger females who become the first partners of these males are more likely to be infected themselves.

The comparatively low seroprevalence in this study of a cohort characterised by a high level of sexual activity casts some doubt on the suggestion that HSV-2 seropositivity can serve as a proxy marker for high risk sexual behaviour, at least in a general population sample that is as young as 21 years of age. It is notable that for both sexes the prevalence of HSV-2 antibodies in subjects at very high risk of acquiring STDs remained relatively low.

Limitations in the use of HSV-2 seropositivity as an indicator of sexual activity among populations has already been demonstrated in the United States, where blacks with one lifetime partner are more than four times as likely to be infected with HSV-2 than whites with one lifetime partner. ${ }^{6}$ This finding might be explained by differences in HSV-2 prevalence in the pools of potential partners for each group. Similarly, there may not yet be a critical mass of HSV-2 carriers in the pool of potential partners for 21 year old New Zealanders, allowing them to escape with a low seroprevalence in spite of high risk behaviour.

This study was funded by the University of Otago Medical School Bequest Funds. Subjects came from the Dunedin Multidisciplinary Health and Development Study, funded by the Health Research Council of New Zealand, under the direction of Dr Phil Silva. We thank Brownen McNoe for data entry, and Peter Herbison and Dr Katrina Sharples for statistical assistance.

1 Breinig MK, Kingsley LA, Armstrong JA, et al. Epidemiology of genital herpes in Pittsburgh: serologic, sexual, and racial correlates of apparent and inapparent herpes simplex infections. F Infect Dis 1990;162:299-305.

2 Koutsky LA, Ashley RL, Holmes KK, et al. The frequency of unrecognised type 2 herpes simplex virus infection among women. Implications for the control of genital herpes. Sex Transm Dis 1990;17:90-4.

3 Cowan FM, Johnson AM, Ashley R, et al. Antibody to herpes simplex virus type 2 as serological marker of sexual lifestyle in populations. BMF 1994;309:1325-9.

4 Cunningham AL, Lee FK, Ho DWT, et al. Herpes simplex virus type 2 antibody in patients attending antenatal or STD clinics. Med F Aust 1993;158:525-8.

5 Siegel D, Golden E, Washington AE, et al. Prevalence and correlates of herpes simplex infections. The populationbased AIDS in multiethnic neighborhoods study. $¥ A M A$ 1992;268:1702-8.

6 Fleming DT, McQuillan GM, Johnson RE, et al. Herpes simplex virus type 2 in the United States, 1976 to $1994 . \mathrm{N}$ Engl f Med 1997;337:1105-11.

7 Bassett I, Donovan B, Bodsworth NJ, et al. Herpes simplex virus type 2 infection of heterosexual men attending a virus type 2 infection of heterosexual men attendin

8 Gibson JJ, Hornung CA, Alexander GR, et al. A cross-sectional study of herpes simplex virus types 1 and 2 in college students: occurrence and determinants of infection. F Infect Dis 1990;162:306-12.

9 Nahmias AJ, Lee FK, Beckman-Nahmias S. Seroepidemiological and sociological patterns of herpes simplex virus infection in the world. Scand $\mathcal{F}$ Infect Dis 1990 69(Suppl):19-36.

10 Silva PA, Stanton WR, eds. From child to adult: the Dunedin multidisciplinary health and development study. Auckland: Oxford University Press, 1996.

11 Dickson N, Paul C, Herbison P, et al. The lifetime occurrence of sexually transmitted diseases among a cohort aged 21. NZ Med f 1996;109:308-12.

12 Ho DWT, Field PR, Sjogren-Jansson E, et al. Indirect Ho DWT, Field PR, Sjogren-Jansson E, et al. Indirect
ELISA for the detection of HSV-2 specific IgG and IgM ELISA for the detection of HSV-2 specific IgG and IgM
antibodies with glycoprotein $\mathrm{G}(\mathrm{gG}-2)$. I Virol Methods 1992;36:249-64.

13 Perkins NL, Coughlan EP, Franklin RA, et al. Seroprevalence of herpes simplex virus type 2 antibodies in New Zealand sexual health clinic patients. NZ Med f 1996;109: $402-5$.

14 Christenson B, Bottiger M, Svennson A, et al. A 15-year surveillance study of antibodies to herpes simplex virus types 1 and 2 in a cohort of young girls. $\mathcal{F}$ Infect 1992:25:147-54.

15 Mertz GJ, Benedetti J, Ashley R, et al. Risk factors for the sexual transmission of genital herpes. Ann Intern Med 1992;116:197-202.

16 Tobias MI, Hermon YE. Changing patterns of genital herpes. NZ Med F 1983;96:684-6. 